\title{
The Ethnic Composition of Bohai State on the Archaeological Materials
}

\author{
Olga V. Dyakova \\ Institute of History, Archaeology and Ethnography of the Peoples of the Far East, \\ Far Eastern Branch of the Russian Academy of Sciences, Vladivostok, Russia \\ Email: emelianova49@mail.ru
}

Received October 28 $8^{\text {th }}$, 2013; revised December $8^{\text {th }}$, 2013; accepted December $19^{\text {th }}$, 2013

\begin{abstract}
Copyright (C) 2014 Olga V. Dyakova. This is an open access article distributed under the Creative Commons Attribution License, which permits unrestricted use, distribution, and reproduction in any medium, provided the original work is properly cited. In accordance of the Creative Commons Attribution License all Copyrights (C) 2014 are reserved for SCIRP and the owner of the intellectual property Olga V. Dyakova. All Copyright $@ 2014$ are guarded by law and by SCIRP as a guardian.
\end{abstract}

Setting the Problem: Pohai State (698-926), being situated on the territory of the Russian Primorye, North East of the Democratic People's Republic of Korea and North East of China, was created by Tungus-Manchus tribes Sumo Mokhe. Pohai was a poly-ethnic (multinational) state. Tribes Mokhe were the basic population of it. Besides, there lived Koguryo, Paleo-Asian and Chinese residents. Each ethnic community had its own social status that could be determined by archaeological material. For deciding such a task the author worked out methods for determining the structure of archaeological culture. In the Russian archaeology the term "archaeological culture" means a complex of archaeological sites situated on one and the same territory and possessed common indications of material culture (ceramics, artifacts out of metal, necropolis, dwellings, etc.). Structure of Mediaeval Archaeological Cultures: The author proposes to single out three layers in material culture: aboriginal layer contains the information about ethnic belonging; state layer characterizes handcraft production and gives a possibility to determine the state borders; epoch layer gives a possibility to date sites and single out military-trade-economic ties. The aboriginal layer is represented with artifacts being made by residents themselves. They are molded ceramics, traditional decorations, the specificity of dwelling construction, funeral rites, etc. The state layer is represented with handicraft artifacts, mainly, made by alien masters and with technology different from the aboriginal one. For example, ceramics being produced on the potter's wheel; types of fortifications that were built by special (foreign) masters invited for it, and etc. The epochal-making layer is represented with artifacts that were spread on the very vast territory, for example, girdles (belts) of Turk type, ceramics of Tan dynasty, armament, etc. Three Tasks of the Investigation: According to such methodic principles there were set three tasks: on the archaeological material to single out the ethnic (aboriginal) structure of Pohai state; to determine state signs; to define social status Koguryo residents in Pohai. Analysis of the Material: Ceramics. The analysis of molded ceramics exposes that on Pohai sites there was present only Mokhe type of the vessels. There is no molded Koguryo ceramics there. The analysis of ceramics, being finished off on potter's wheel, exposes handicraft traditions and the presence of kilns, i.e. potter's wheel ceramics of Koguryo type were produced there. The analysis of potter's grey-clay ceramics exposes handicraft traditions of Tan dynasty but the absence of centers of its production. It is indicative of trade relations. Fortifications: The appearance of stone mountain sites in Pohai is connected with fortification traditions. The appearance of valley (plain) square sites is connected with Chinese fortification traditions. Conclusions: So, the basic (aboriginal) population of Pohai was Tungus-Manchus tribes Mokhe. Koguryo residents in Pohai were used as potters-handicrafts men and fortification masters and, may be, warriors. The geography of stone fortresses shows up that they were constructed for defending marine and land roads.

Keywords: Mediaeval Archaeological Culture; Koguryo Residents; Pohai State

\section{Introduction}

It is known from written sources that as for structure of population the Tungus-Manchu state Pohai (698-926) was poly ethnic (multinational) one and consisted of tribes: Mokhe (Malgal), Paleo-Asiatics, Chinese, Koguryo residents. The social status of these tribes and ethnic communities in Pohai state has not been determined yet. It is known that a considerable number of Koguryo residents came to Pohai after the fall of
Koguryo state. Moreover, scientific debates are continued concerning to ethnic belonging of the first Van of Pohai statewhether he was of Mokhe origin or belonged to Koguryo tribe. But in this report I intend not to analyze the ethnic origin of the first Van of Pohai but to determine the role, significance and social status of Kogurye residents in Pohai state. Written sources are quite scanty and give no opportunity to solve this problem objectively. In fact only archaeological artifacts are 
preserved. And I intend to use them.

\section{Structuring Mediaeval Archaeolodgical Culture}

There have been three sources of information about the mediaeval Far East: 1) written evidence dealing with affairs of state, political boundaries, and the economies of the states of Bohai and Jurzhen; 2) the remains of fortified sites, roads and craft centers; and 3) handicraft products such as wheel-made pottery or metallic articles found in profusion, along with many other objects during excavations at the urban and burial sites of the Bohai and Jurzhen cultures. Most scholars are still quite content with the existing interpretations of this information, even though many are merely romantic exaggerations, among which, unfortunately, must be counted some descriptions of the cultures of these particular societies. It is our contention, however, that these interpretations display instead the apparent failure of an approach to the study of mediaeval archaeological cultures restricted to the considering of only one aspect, namely, the urban cultural sphere, whose characteristics are very much alike throughout various cultures due to the effects of industrial development, yet whose origins are not necessarily native. It is hardly questionable that governments, not excluding medieval ones, often promoted crafts with the help of foreign craftsmen brought in for just such a purpose. As a result, new types of wheel-made clay ware, as well as other goods, came into being. They had neither intrinsical links to the culture and traditions of the local populace nor any domestic prototypes. Therefore, we conclude that within the existing approach to a survey of mediaeval sites in the Russian Far East, the genuine aboriginal culture has literally fallen out of the sphere of most researchers' attention. Attempts have been made to solve basic problems of ethnical and cultural processes in their full complexity ${ }^{1}$ while drawing on rather irrelevant materials. This situation has prompted us to work out a structural scheme of mediaeval archaeological culture to make it clear how a given group of traits relates to a broad analysis of a given culture. An analysis of the entire body of mediaeval data brought from each of the Far Eastern sites allowed us to speak of the three major subdivisions within an archaeological culture. They may be defined as 1) culturally indicative (aboriginal), 2) regional (those characteristic of a particular state), and 3) epochal. As culturally indicative we define those traits represented by items embodying aboriginal traditions, and thus suitable for reconstructing not solely the processes of cultural development (culturogenics), but ethnical dynamics as well (ethnogenics). Among such items the foremost importance belongs to handmade clay ware produced by the cultural tradition bearers of a given culture themselves. It can serve as a clear-cut recognition symbol of a culture. Handmade ware could not spread outside a limited area and as a rule, this area coincided precisely with that of the archaeological culture. To regional traits (those characteristic of a state) we attribute objects produced, to a greater or lesser degree, with the use of industrial methods of manufacture, including, of course, wheel-made ceramics. Their distribution was related with the activity of craft centers (workshops, "schools", "families", "kilns"), whose influence seldom reached beyond the official state boundaries. Therefore, traits of this type can be indicative of a particular state. Items of this category may reflect both domestic and adopted foreign traditions. This may lay the groundwork for reconstructing patterns of political and merce-

\footnotetext{
“"Ethnogenesis” or ethnogenics, and “culturogenesis” or culturogenics, respectively, as Russian terminology puts it.
}

nary contacts but is of little use when it comes to understanding the ways of ethnical changes (ethnogenecs). Shapes and decorations of vessels and other objects within this category could change easily, subject to vogues of the time, a ruler's tastes, or requirements imposed by a certain social straum, whereas technique and technological traditions were usually prone to stability.

Classified as epochal need to be those cultural elements which prove more or less ubiquitous, regardless of geographical or political barriers, and, as characteristic traits, belong to no particular society but to a definite time span. Such would be Turkic belts, Mongol arrowheads, selected types of wheel-made pottery, or certain designs of ornamentation, to mention just a few. They are good for dating complexes and cultures, or attesting to martial, economic or religious events and interactions, but are in no way suitable for building reconstructions of the patterns of ethnical changes.

To sum up, we believe that any mediaeval archaeological culture has to be analyzed as a triplex structure that comprises three groups of traits: aboriginal, regional (those relating to a state) and epochal. This approach makes not only answering questions about cultural roots, changes and chronology possible, but also lets us advance to more adequate historical associations and realistic interpretations, not in the least those helping to solve the problem of the genesis and development of particular states in this area.

\section{Task One}

To answer the question: what ethnic communities were the native (indigenous) population of Pohai state? Ceramics is the most objective material in this case. Vessels out ceramics, that were discovered in archaeological sites of Pohai culture in the North-East of China and on the territory of the Russian Primorye are the basic material (Figure 1). My analysis of ceramics revealed that as for technique it is represented by three categories of articles: modeled vessels, ceramics, being completed on potter's wheel and potter's ceramics. All these three categories are done with different technique, that is on different ethnic traditions. The first category-modeled ceramics made with circular band model (Figure 2).

Its forms are vases, pots, jars with modeled cylinder under the top, decoration and technique of modeling are traditional for Mokhe tribes (Malgal). Modeled earthenware was made by native indigenous population. Such type of vessels-Mokhe one-was developing on the territory of North East China and the Russian Far East (Priamurye and Primorye) for more than one thousand years. Such earthenware is characteristic for Mokhe culture (Malgal), culture of the Amur Jurchen and it could be met almost on all Pohai sites. In Koguryo state the other modeled earthenware was traditional, and it is absent on Pohai sites. So, the main indigenous residents of Pohai state were the tribes of Mokhe (Malgal), that is the Tungus-Manchus.

\section{Task Two}

To determine Kogurye materials on Pohai sites. In this case we could use the second category of ceramics - handicraft pots of definite form, decoration and proportions, modeled on potter's wheel. They are met on all Pohai sites and are analogous to Kogurye handicraft pots (Figure 3).

Such type of earthenware is marking Pohai cultures and is defined as Pohai ceramics of Koguryo origin. Besides of Pohai 


\section{O. V. DYAKOVA}

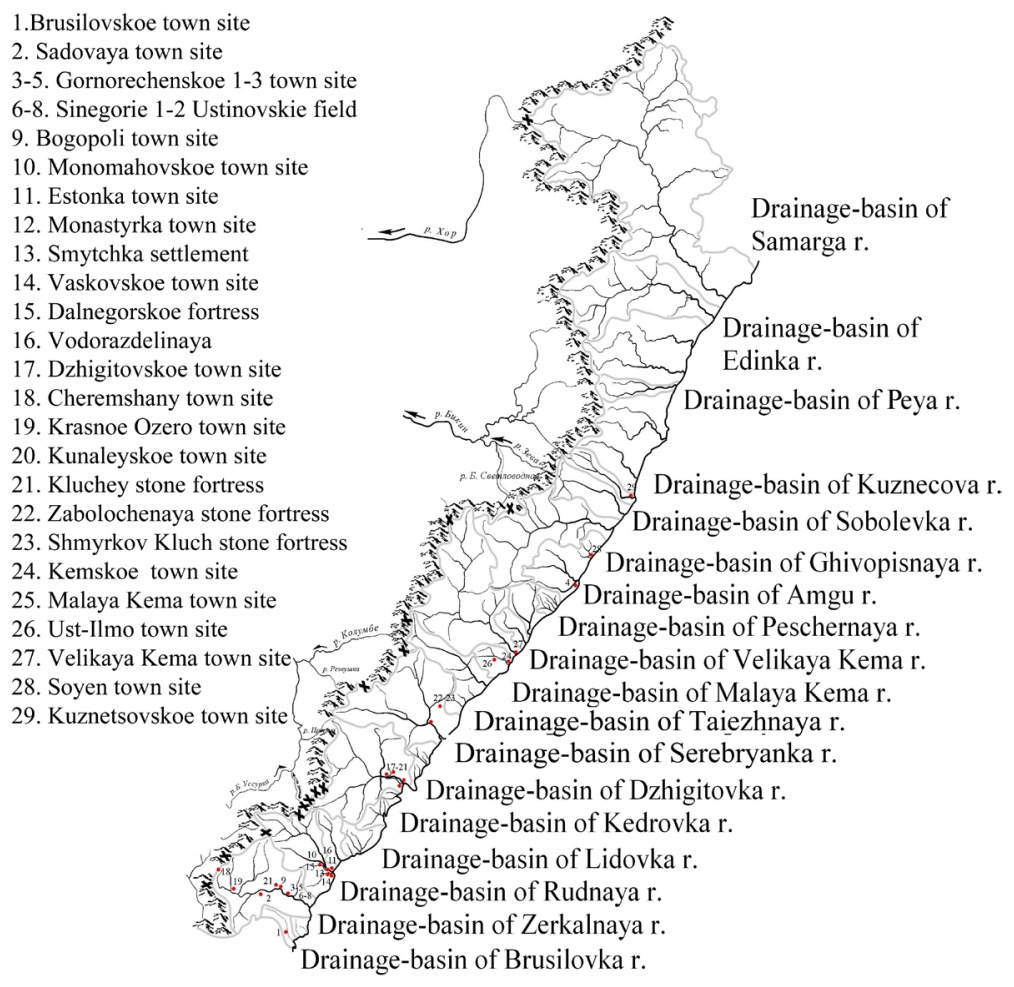

Figure 1.

The map of Pohai sites of the North East Primorye.

\section{Bohai culture of Primorye Group1 Handmade pottery}

1- Maryanovskoe town site

2, 5 - Konstantinovskoe 1 settlement

3 - Novopokrovskoe grave

4 - Nikolaevskoe 1 town site

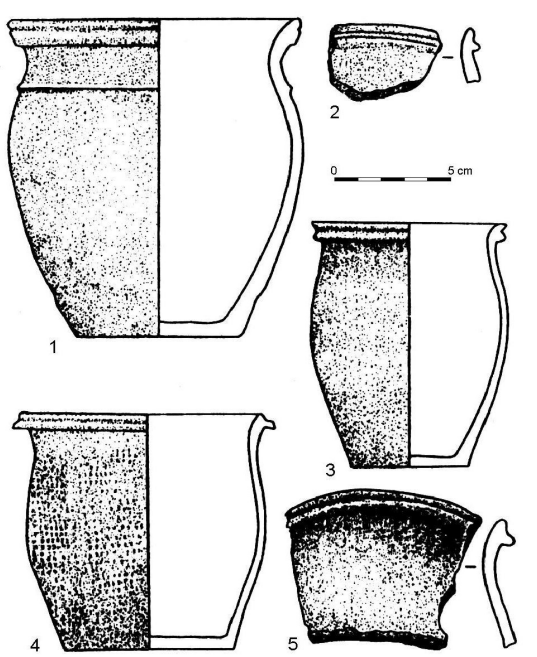

Figure 2.

Bohai culture of Primorye Group 1. Handmade pottery; Novogordeevskoye town site, Konstantinovskoye village, Kraskinskoye town site, Petrovskoye village.

pots, in Pohai culture of sites of North East Primorye-Sinegorye 1 -there appeared long potter's kilns being traditional for Kogurye. That is, the appearance on Pohai sites handicraft Koguryo earthenware is not a result of trade-economic relations when earthenware would be bring over from anywhere. The presence of potter's kilns-is an index of native production and indirect presence on Pohai monuments of Kogurye potters.
Judge by a number of potter's articles, there were quite a number of Koguryo potters in Pohai and such was the situation not only in central provinces but on the outskirts of state. For example, it was so in the north-east of Primorye where there were discovered kilns of Koguryo type and the very ceramics itself. So the conclusion is that in Pohai state Koguryo residents represented the strata of crafts-men. 

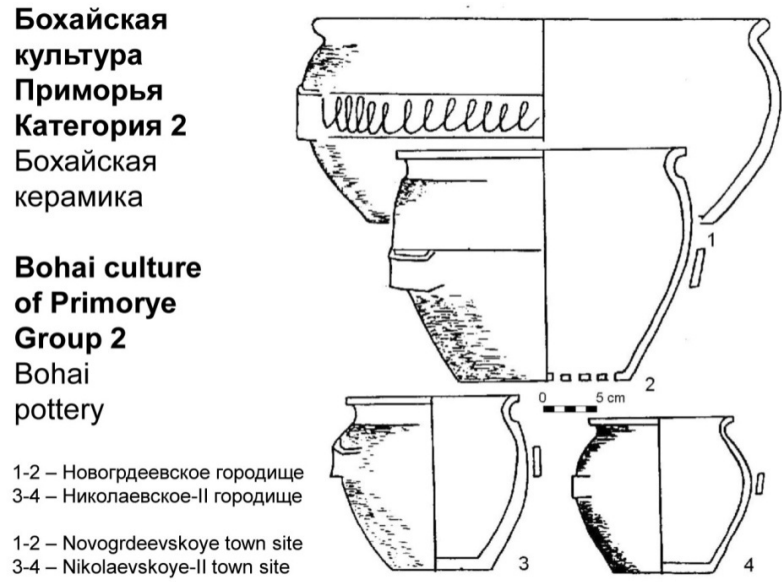

(a)

\section{Бохайская \\ культура \\ Приморья \\ Категория 2 \\ Бохайская \\ керамика \\ Bohai culture \\ of Primorye \\ Group 2 \\ Bohai \\ pottery}

Николаевское-2 городище Nikolayevskoye-2 town site

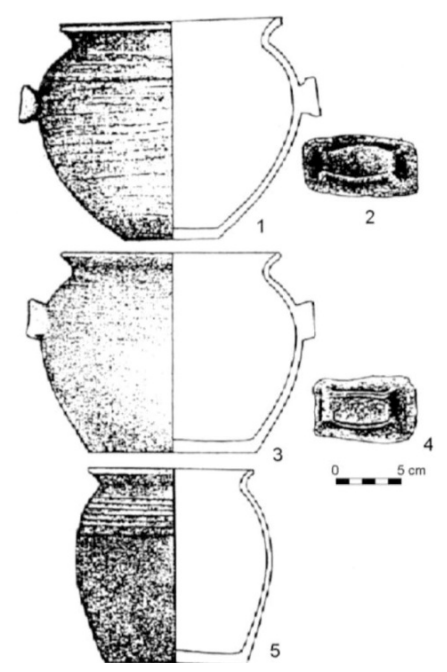

(c)
Bohai Culture of Primorye. Group 2. Bohai pottery

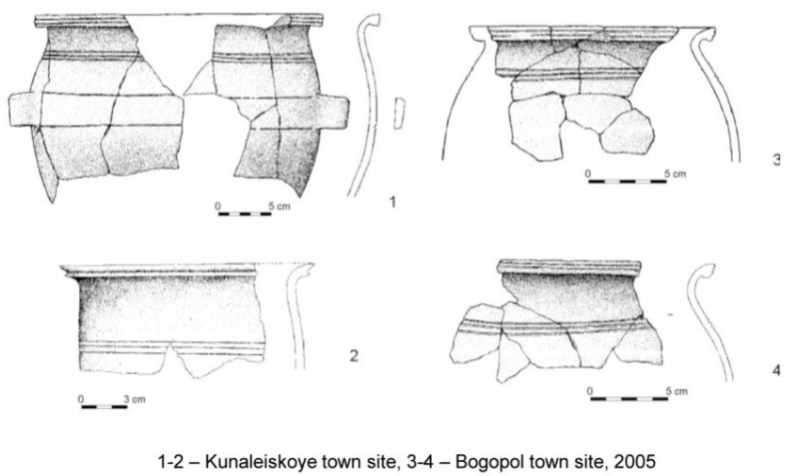

(b)

Bohai Culture of Primorye. Group 2. Bohai pottery

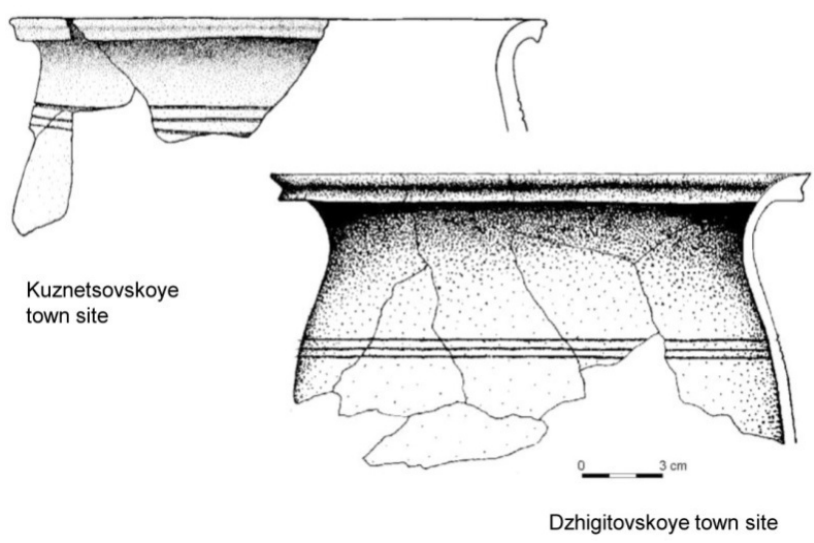

(d)

Figure 3.

Bohai culture of Primorye. Group 2. Bohai pottery; Novogrdeevskoye town site, Nikolaevskoye-II town site, Kunaleiskoye town site, Bogopol town site, Kuznetsovskoye town site, Dzhigitovskoye town site Sinegorye dwelling site Nikolayevskoye-2 town site.

\section{Task Three}

To show: what function, besides handicraft one, was exercised by Koguryo residents? This task could be seen through analyzing fortification constructions. After the fall of Koguryo state on the territory of Primorye, in particular in the north-east, there appeared stone fortresses that were constructed according to Koguryo traditions. They were built out of stones (rocky) and without cement linking. Stones had got special trim, and walls became solid. Stone fortresses on isolated hills are located on the tops of separately standing hills, often rock outcrops, and are built of stones without cementing. Positioned so as to dominate local landscapes, such fortifications permit a good view of neighboring valleys and obviously must have served strategic purposes. Today we know of ten stonework fortresses in Primorye, six of them are located in central Sikhote-Alin mountain range and on East Sea's (Sea of Japan's) eastern and northeastern coasts: Shmyrkov Klutch, Zabolotnoye (Altar) in Serebryanka river basin, Klutchi (Dzhigitovka river basin), Vaskovskoye (Rudnaya river basin), Seselevskoye (Zhivopisnaya river basin), Yashu. Planigraphy of stone fortresses is simple. The builders chose flattened areas and adjacent surfaces available on suitable hills. Fortifications consist of round or serpentine stonework walls encircling a hill. Constructing technologies are interesting for the presence of persistent technical patterns and ultimate skill. Building stone was usually procured on the locality. Durability of walls highly depended on methods of stone processing. Prior to raising of wall, builders would flatten an underlying surface. The width of a stripe to be flattened was up to $2-6 \mathrm{~m}$. It was to be covered with a layer of big stones, specially processed-each piece of stone had a raised border on its edge so that an overlying stone would not slip. Stones in the upper layers are pyramidal in shape. The higher the layer, the smaller the stones. It seems that the size of stones was standardized for each layer. The shape of the stones has some notable particularities - each stone was rectangular in the base, had rounded corners in the middle, and was tapered at the top. The lowest part of the wall on the inside was staircase-shaped (Figures 4 and 5).

To sum up, the stone-built mountain fortresses can be characterized by the following features: placement in strategically important localities atop dominating heights; the use of 


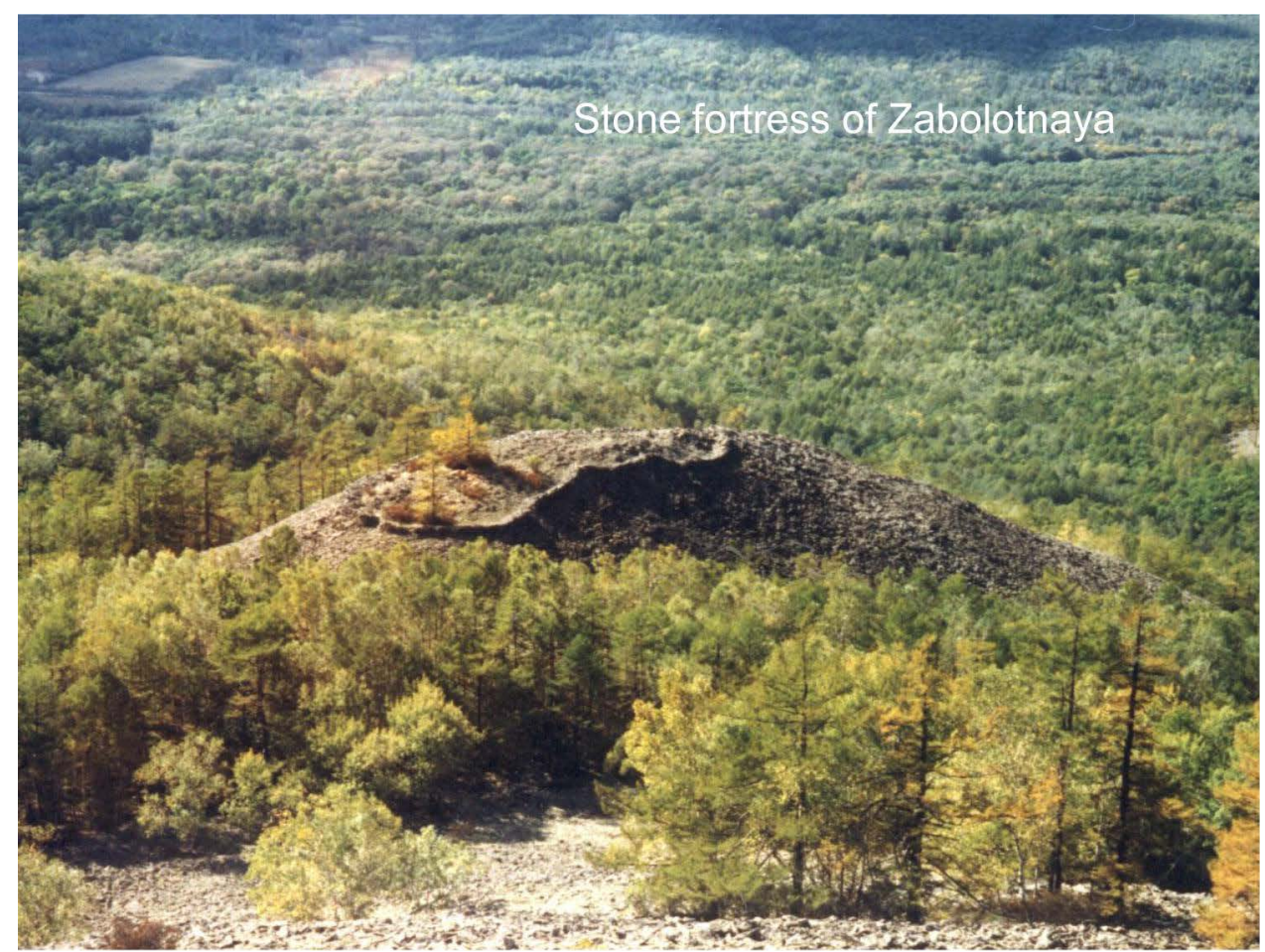

Figure 4.

Stone fortress of the North East Primorye; Zabolotnaya.

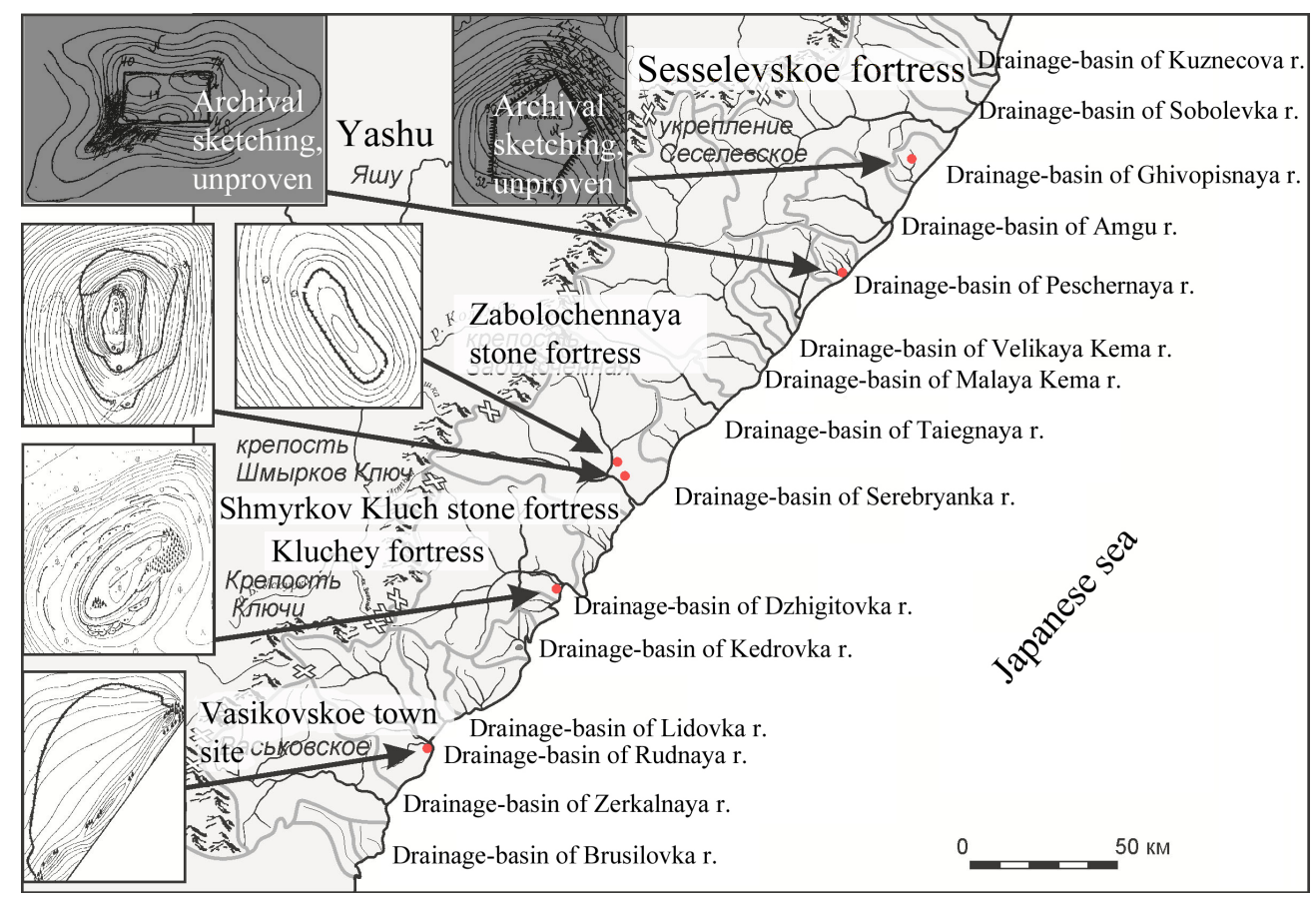

Figure 5.

The map of the Stone Fortresses of Northeastern Primorye.

local building material; lack of cementing; standardized stone shapes and sizes of certain wall parts; staircase-shaped inner wall configuration; absence of continuous vertical seams; artificial flattening of hill surface before construction. According to collected data, stonework fortresses were built during the
Mohe and Bohai times.

This method was widely used only by Koguryo representatives. The Mokhe residents never built such fortresses. These fortresses were situated on separate hills, usually on bare territory, on dominating hills giving opportunity to control all en- 
trances to the valleys. There are ten such fortresses: in Yashu, Zabolotnaya, Shmyrkov Kliuch, Vas'kovskoye site, Kliuchi, Soenskon site. So, a definite part of Koguryo residents was on military service, and judging to location of stone fortresses, Pohai used them for defending his boundaries, in particular, of North East Primorye.

By choice of location, constructing methods, and purposes, stone fortresses of Primorye derive from fortification traditions of Koguryo fortresses, often being virtually identical with those. Perhaps this tradition of arranging a fortified site was adopted by the Mohe and Bohai not before 7th century AD, i.e. after the downfall of Koguryo state and Koguryo people having become the Bohai citizens.

The Koguryo traditions in medialval town-planning in Primorye. The construction technology used in northeastern Primorye to erect stone fortresses (Shmyrkov Klutch, Zabolotnaya, Klutchi, Vaskovskoe Ozero) obviously reproduces the Koguryo technology and actually derives from the latter.

With Koguryo bulders, just the same way as with the Jurzhen from East Xia State, the main criteria of choosing a building location were precipitous mountainous landscape and presence of large river.

Of 176 Koguryo town sites found in northeastern China and North Korea only 56 have been researched. Among them there are 47 stonework fortresses and only 9 earthen ones (Sokson, Ensonja, Thapsan, Koi, Puksansondja, Rendam, Sariho, Mokki, Hongenno in Manchuria and Anhak in North Korea). The author have already published her study of links between mediaeval stone fortresses of Russian Primorye and Koguryo, thus no point in elaborating on this here. We must remember though that construction technology used in northeastern Primorye to build stone fortresses (Shmyrkov Klutch, Zabolotnaya, Klutchi, Vaskovskoe Ozero) obviously reproduces the Koguryo technology and actually derives from the latter (Dyakova, 2005). All the more so because ceramic materials from the above mentioned Primorye's fortresses are comparable with the Mohe and Bohai traditions, contemporaneous with the Koguryo culture. It is known that military and technical innovations spread fast enough. Koguryo's fortified earthen mountain towns, as opposed to stone fortresses, are scarcely explored for various reasons. For a long time Korean, Chinese, and Russian scholars worked separately in their own countries. Today we have got an opportunity to analyze and compare the results relevant to the problem of genesis and development of mediaeval fortifications in the Far East. Geophysical parameters of Russian Primorye, northeastern Korea and northeastern China are similar enough, and this fact should have in similar way influenced the process of choosing a location by inhabitants of these territories when it came to building a fortified site. The choice would be dictated by landscape. The Koguryo people as well as the Jurzhen from East Xia preferred a steep mountainous topography and presence of large river. Korean written sources state that, as a rule, the Koguryo placed their mountain towns on hilltops facing the lowlands. "... Outside the fortresses they raised earthen bulwarks to prevent the use of ladders and visibility of actions inside the fortress... Even if enemies fiercely attacked, their hike from the base of the hill to the fortress exhausted them, they breathed interruptedly, their ardor died away, while our soldiers remained calm, inspired and ready to fight against intruders by letting big boulders roll down the hill-enemies fell right on the run” (Un, 2005). Kim Gi Un wrote that the Koguryo mountain towns were always found in the presence of water source. Water not only provided means of transportation, but served as a natural border helping to control an enemy's movement and limiting the latter's maneuverability (Nosov, 2001). To build mountain towns, the Koguryo chose places near the valleys inhabited by people who could supply human force as well as food, yet find shelter in the fortress in dangerous situations. Such pattern is comparable to the Jurzhen of East Xia's. An unconditional rule for the Koguryo to choose a place to build a town was the presence of convenient means of transportation, i.e. waterways and roads, permitting both maneuverability and communicability with neighboring fortresses. The Jurzhen obeyed the same rule, as we noted before. All of the Koguryo's mountain towns were crossed by rivers or streams, otherwise had ponds and wells. For example, according to ancient scripts, the Koguryo town of Taeson had 99 ponds plus a brook. The East Xia's Jurzhen provided themselves with water the similar way. To ensure the combatant value of their towns the Koguryo paid ultimate attention to reinforcement of fortress walls, the basic fortification element. Like the Jurzhen, the Koguryo builders erected watch posts and towers over gates. Near a gate the fortress' wall was usually duplex, while in front of the gate there was a protective wall with embrasures at sides, known as "chokte". Watch posts, as a rule, helped to strengthen wall corners and served as command posts. Similar constructions are typical for mountain towns of Jurzhen too. With Koguryo fortresses, an important defensive role played embrasures placed so as to permit shooting at an enemy directly or from sides. Before the invention of embrasure it was impossible to shoot at the troops which had made their way right under the walls. Korean scholars believe embrasures to be a Koguryo's invention while protective walls, gates in the wall without tower, defensive lines, and double walls to be distinctive features of Koguryo mountain fortresses. Having analyzed Primorye's mountain towns belonging to the Jurzhen of East Xia and Koguryo's mountain fortifications, we come to the conclusion that the influence of Koguryo's fortifications on the development of Jurzhen type of mountain towns was an immense one. To say the least, the Jurzhen people did adopt Koguryo's principles of placement of fortresses in mountainous landscape. Those principles include the following: protection by hills on three sides, while on one side, usually southern, the presence of water-containing ravine; methods of obtaining and keeping fresh water; distribution of fortification $n$ elements (on the wall, at gates, by corners). At the same time Jurzhen's mountain towns retained some Chinese fortification traditions, Hantu earthen wall-mounds in the first place. It is known that from the ancient times Chinese towns were surrounded with earthen walls where the filling soil was put in layers, each layer being rammed by special wooden rollers. As a result, the walls became very firm and reached eight meters in height. This method have been known in China since 4th century BC, and since 6th century BC the Chinese have used stone lining of curtain-walls and built the towers. Apparently the Koguryo adopted the method of erecting earthen walls from the Chainese as early as in antiquity, but further adapted it to mountainous environment. On the other hand, by geomorphology as well as fortification and constructing technologies the stonework mountain fortresses built by the Mohe and Bohai peoples correspond well with Koguryo traditions and appear to be derived from the latter. Thus we are to conclude that in Primorye the two types of mountain fortified sites built by mediaeval Tungus-Manchurians - the Mohe, Bohai, and Jurzhen 


\section{O. V. DYAKOVA}

peoples-obviously meet the requirements typical of Koguryo's town-building traditions, having been, as it seems, founded on the latter.

\section{Conclusion}

Thus, the analysis of archaeological material let such conclusions be made: the indigenous residents of Pohai state were tribes of Mokhe (Malgal). After the fall of Koguryo a considerable number of Koguryo residents joined Pohai state. It was so significant that Koguryo earthenware became the principal indicator. Therefore, a certain part of Koguryo residents got the status of crafts-men, in particular, potters. The presence of stone fortresses, being built according to Koguryo building traditions, shows that in Pohai there were a considerable number of Koguryo fighting men and fortification builders (masters) building stone fortresses and defending borders. Undoubtedly, some part of Koguryo residents bore a relation to administrative system of Pohai, but it is difficult to trace it according to archaeological data. Evidently, Koguryo peasants inculcated agri- cultural practice to Tungus Manchus population of Pohai, but there are few archaeological facts on it yet.

\section{Acknowledgements}

The work is done under financing of grant by RGNF No. 12-31-09008.

\section{REFERENCES}

Dyakova, O. V. (2005). Gorodischa i kreposti Dalnego Vostoka (severovostochnoye primorye). (Ancient Town Sites and Fortresses of Far East. (Northeastern Primorye)). Vladivostok, 171.

Nosov, K. S. (2001). Zamki i kreposti Indii, Kitaya i Japonii (Castles and Fortresses of China and Japan). Rejttarj, Moscow, 27.

Un, K. G. (2005). Research of Particulariries of Koguryo Mountain Towns (pp. 138-152). Separately printed copy. Similar characterization of Koguryo towns was offered by Prof. Nam Il Ren, University Kim Il Sung, at Second International Conference on Korean Studies. 